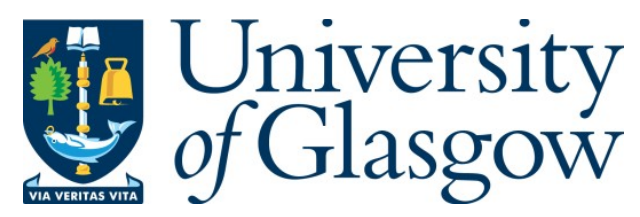

Walton, H. (2020) A theopoetics in ruins. Toronto Journal of Theology, 36(2), pp. 159169.

(doi: 10.3138/tjt-2020-0082)

This is the Author Accepted Manuscript.

There may be differences between this version and the published version. You are advised to consult the publisher's version if you wish to cite from it.

http://eprints.gla.ac.uk/219398/

Deposited on: 30 June 2020

Enlighten - Research publications by members of the University of Glasgow http://eprints.gla.ac.uk 


\section{A Theopoetics in Ruins}

\section{Prologue}

As a theologian and a writer I am fascinated by a terse passage from the second chapter of John's gospel. Jesus is introduced as the 'zealous' defender of the temple of God. Yet straight away announces its destruction and impossible restoration: "Destroy this temple, and in three days I will raise it up." His critics respond "It has taken forty-six years to build this temple, and will you raise it up in three days?" The passage ends "But they did not know he was speaking about the temple of his body.' (John 2:19)

I am drawn by both the ambivalent relation to tradition and also the striking poetic contrasts, elisions, relations and transformations this small narrative contains. The sacred building in ruins; the body damaged, wounded and destroyed. Stone and flesh in derelict communion. That which is solid and insensible bleeding into what is warm, fleshly, mortal and vulnerable. A body in ruins. Broken stone-flesh faith.

The alters have been torn down and the stones scattered. What was once so vital and so warm is still; silent.

In his important book 'Rejoicing' subtitled 'The Torments of Religious Speech' (2013) cultural theorist Bruno Latour speaks of the pain of remaining a religious observer in a culture that has lost all comprehension of theological discourse. 'There is no way of saying these things anymore...no regime of speech or utterance (2013:1). [What] metamorphosis makes what once had so much meaning become absolutely meaningless?' (2013:2). 'All together we pray in the shadows of this rubbish tip that's as high as a hill, ready to come streaming over

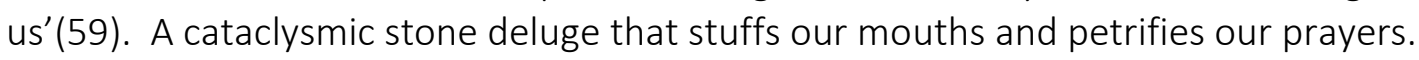

Latour is not the theologians' favourite interpretor of secularisation (post or otherwise). We have not 'rejoiced' in his statements on the status of religious discourse. Charles Taylor is a sweeter friend. In his monumental work, A Secular Age (2007) Taylor asserts that the decline of a sensibility for the transcendent within culture is accompanied by an oppressive sense that something precious has been lost (2007: 307). For Taylor this loss is not only spiritual and intellectual it is visceral. The world appears soiled and ugly. It has been emptied of enchantment and the way we live 'has no meaning, beauty depth, sense. There can be a kind of 'nausée' before this meaningless world' (2007: 308). The work of members of the theological guild appears justified by this analysis. As traders in transcendence we are redeemed from our sense of tortuous irrelevance and restored to the position of guardians of life, beauty, depth and meaning in opposition to what is often characterized as the atheistic nihilism of present age (see, for example, Milbank, 2013; Smith, 2014). It has fallen to us to keep precious things alive - if carefully concealed. Furthermore, Taylor's Hegelian approach appears to hold out some hope for a renewal of theological thinking if we continue to practice our arcane discipline whilst enduring exile in the 'wastelands' of the imminent plane (2007: 770). 
In a very different mode to Taylor Bruno Latour has consistently argued that there is no loss of vitality and enchantment in contemporary life that we are called upon to restore. The problem is not a spiritual sickness but a theological failure.

$[\mathrm{H}]$ ow many years has it been, how many centuries, since those professionals of the word... found themselves in a contemporary period they did not hate with all their guts? Idols, materialism, the market, modernism, the masses, sex, democracy everything has horrified them... They really believed that you couldn't possibly speak of religion except by first deporting peoples ... [somewhere] supposedly more 'spiritual'. ... As for me, this world suits me down to the ground...I don't have any other, what's more. There is no other world, just this one here, the only one we have to be seized again quite differently' (2013: 173-4)

Latour speaks to my own experience of contemporary culture as vibrant and alive; full of intimations of enchantment and lively presencings of the divine. However, I would incorporate into this understanding an awareness I draw from the work of Henri Lefebvre that - whilst a 'veritable profoundness shines through' (2002: 65) everyday existence - the tragic also irrupts into our experience unsettling and utterly reshaping it. Lefebvre writes that whoever 'does not shy away from the horror of the world, the darkness, but looks it straight in the face... passes over into a different kingdom ...[to] traverse daily life under the flash of the tragic is already to transform... (2005: 171-2). Political theorist William Connolly combines these insights to argue that a sense of the sweetness of life must be shot through with a tragic sensibility if we are to truly engage with the political, social, spiritual and ecological challenges that confront us (2012: 181).

For me then, the challenge is to seize again this world of wonders and horrors - quite differently. But grasping and revisioning religious speech within a postsecular or enchanted understanding of culture is difficult work. It entails, first of all, comprehending that the theological edifice is no longer habitable but stands in ruins. It then requires an acknowledgement that this destruction is not simply to be regretted. Theology does not simply lack imagination and communicative vitality. It has also been dreadfully complicit in the abuse of power and profoundly neglectful of human suffering. What is needed is the confrontation of theology with claims it has denied and the creation of God-speech beyond the forms in which it is currently expressed. I am seeking a 'theopoetics' that can communicate in the context of broken, stone-flesh faith.

\section{Theopoetics and Theology}

Theopoetics is the term used by a vibrant and diverse movement of artists, activists and scholars who fully accept the brokenness of contemporary theology. Indeed, who take this as their starting point. They are not seeking to make theology more attractive, accessible or communicable through enrolling artistic support to its established cause. Leading advocate Catherine Keller writes that a theopoetic approach is not interested in camouflaging, 'the tawdry sanctuaries of dying belief with lovely bouquets of language'(2013: 185) The challenge rather is to conceive the sacred 'quite differently'.

But this process nevertheless entails creative work for art may often embody what conceptual frameworks are, as yet, unable to articulate. This could be because of the 
ambiguity or ambivalence of the subject matter or its novelty and corresponding threat to existing categories of thought. 'The effervescence of language, the force of metaphor, icon, and story (Keller, 2013: 180)', offer means of escape from established, closed and selfreferential theological epistemologies. The libidinal qualities of art also enables theopoetic discourse to risk pollution or the 'indencency' of bringing desiring matter and flesh into relation with sacred speech. Many practitioners reach out towards words and symbols that do not abstract but incarnate. They seek forms of writing, stone-flesh words, that have the qualities of objects and bodies.

But the seeking of stone-flesh words is not principally a poetic device it rather represents an attempt to express deep relationality and encounter in language. Many theopoetic practitioners are proponents of embodied and relational ontologies (see, for example, Rambo, 2017; Rivera 2015). For them poetics refers not only names artistic and creative practices but what Mayra Rivera describes as 'modes of knowing, being, and acting in the world' (2019:). Poetics in this frame represents an attentive response to brokenness and suffering; a similar understanding is found in such revelatory texts as Maurice Blanchot's Writing the Disastor (1995), Paul Celan's The Meridian (2011), Édouard Glissant's Poetics of Relation (1997). Furthermore this responsive act is seen as drawing together the human work of poesis with divine creative work. God is the poet of the world and we are co-creators (Kearney 2018), being drawn into divine becoming - theopoesis (Keller, 2008), responding to the insistence of God (Caputo, 2006). All of these images represent some form of eschatological vision in which future is constructed out of the very resources that are now considered wasted, dead and ruined. 'The stone that the builders rejected has become the cornerstone. (Ps 118:22; Matt 21:42).'

In my own work I have combined some of these understandings and used the image of bricolage to describe theopoetic work (Walton, 2019). The bricoleur (using Levi Strauss's contrast between the bricoleur and the engineer, 2004) is someone who does not have resources of scientific/technological understanding to craft new inventions they are reduced to working with more primal mythic and symbolic forms or retrieving odd and apparently illfitting fragments of things that have been used already and using them again - working with whatever is to hand. 'It might be said that the engineer questions the universe, while the 'bricoleur' addresses himself to a collection of oddments left over from human endeavours' (Strauss 2004: 21). However, I now seek to move beyond the rather folksy 'man in a hut with some nails, planks and a shoelace image', and imagine rather a theopoetics which connects back to Jesus' haunting evocation of broken stone-flesh faith; a theopoetics of the broken form which do not seek to escape the brokenness of religious speech but to dwell amongst its ruins and seek what can be discerned here. I am inspired in this attempt by the work of cultural theorist and unlikely Jesuit, Michel de Certeau. In describing the radical response of the mystics to a similar crisis in religious speech at the birth of the modern era he reflected 'The mystics do not reject the ruins that surround them. They remain there. They go there ... [to] the locus of a wound'(1992: 25).

In the reflections that follow I do not attempt to offer a systematic argument but to make an assemblage of broken forms that together function as a theopoetic reflection on three aspects of dwelling in ruins and remaining at the locus of a wound. 


\section{Ruins Mediate Loss}

How beautiful stand the temple walls. How high, how solid they appear. Yet not on block, one stone will be left standing upon another. The beloved body is missing and we do not know where it is laid.

I begin by introducing Rose Macaulay - a writer of middle brow popular fiction who towards the end of her life beginning in the years immediately after second world war began to produce remarkable ruin writing.

This did not come out of nowhere. It was born of a personal crisis. Macaulay had lived through the London blitz. She drove ambulances. Very badly apparently. You were in more danger if she picked you up than you were lying in the street. Her flat had been bombed and she had all lost her possessions. But much more traumatic than these things was the death of her lover, Gerald O'Donovan, a married man with whom she had had a secret relationship since the end of the great war. As she lived among the ruins of London and the ruins of her former life she took the broken fragments and their betokening of the lost beloved's body and wrote from them her most widely admired novel. The World My Wilderness (1983).

This is a sparse, modernist fable concerning a young woman, Barbary, who has been involved in the French resistance - seen too much, done too much. It is implied she may have participated in the execution of her German soldier lover and her collaborating stepfather. She is unable to settle into peacetime life and is sent away to live with her uptight British father in London. It is 1946. She comes to a place of ruins and she spends her days exploring these, inhabiting a world collapsed and grown wild. She is particularly drawn to ruined churches. I quote

with their towers still strangely spiring above the wilderness... all this scarred and haunted green and stone wilderness... astir with darting burrowing life, received the returned traveler... Here its cliffs and chasms seemed to say is your home... the margins of the wrecked world, and here your feet are set (1983: 73).

The churches are empty, roofless and open but they mark a place - even if it is only a place of absence. A place where hell is recognised and where important, if uncivilised, spiritual commerce can take place. Barbary recognises their importance. 'If I went to Church, I would go to one of these.' (1983: 57).

As the work reaches a climax Barbary is both nearly destroyed (crushed by the collapsing ruins) and begins a path towards regeneration in her blasted shrine. This does not lead to Barbary's transformation into a civilised creature. Her place of survival and grace lies beyond the confining boundaries of a world that wants to forget its wounds. It must be out there where things lie broken in the 'questionable chaos' amongst the 'shells of churches' (1983: 254) where the beautiful fireweed, the bramble, the bindweed, thorn apple and thistle grow.

There is a telling line in Macaulay's novel... that leads me to my next fragment...' Until you looked [closely] at them and saw they were ruins you would have thought the churches to be going concerns.' (1983: 57) 
In my lifetime I have seen the temples rise and fall. When I was very young my earliest church memories come from the Primitive Methodist Central Hall set amongst rows of smoky, terraced streets in Leeds, Yorkshire. It was a wonderful fantastical space for a child to dwell in. We had amazing concerts. I remember a many-trousered legged dragon arising from the trapdoor and breathing smoke into the audience. Strangely I also remember my Grandad wreathed in clouds of smoke as, cigarette in hand, he peered from behind closed curtains waiting to introduce the next act.

There was a peculiar spiritual dialect that was spoken in this place. It's a forgotten language these days but my mother and I still use it amongst ourselves. So when she is staying with us and looks out of the window at the rain falling on another Glasgow day she sings softly, 'Summer suns are glowing over land and sea'. As I carry in the washing she sings 'are you weak and heavy laden, cumbered with a load of care?'. When she pours herself a glass of red wine she sings 'my drink is water bright' and she intones 'yield not to temptation for yielding is sin' as she reaches out for another meringue. Now that is a subtle tongue. But the world which knew the rhythms of the old speech has gone now.

The old church was demolished when I was five years old and the community moved to a new building on a council estate; modern, bright, multi-functional with a flat roof. There was still great confidence then. We were making a new church for a new age. I remember shortly after the relocation my parents and their friends put on a play but this was not on a stage with curtains. It was in the sanctuary. In this drama Jesus was born in Alabama and was lynched from a tree. There was no smoke or dragons. The actors wore black slacks and sweaters. There was no scenery but a light behind the cross and the stark shadow of a tree falling across the blank wall. The narrative was sung by my mother's friend Rita who stood by the side with by the microphone and marked each heart-breaking moment in her full, sensuous voice. But this church is also gone now. And this hurts. In many ways it's radical vision formed me. Empty for several years it officially closed in 2015. It was demolished this year in March. The site was cleared. There are not even ruins. And where are we now?

Where are we now I mean theologically as people whose shrines are broken and whose language is no longer spoken. Some of us obviously relocating to the theological edifices still standing; noisy speaking places. Others staying in the roofless, broken place. A place of connection to what has been lost. And here perhaps we also learn to speak a language of that connects the brokenness of our domestic altars with deeper silences. This is the conviction which inspires the theopoetic work of Mayra Rivera who draws deeply upon Caribbean writers and in particular the poetics of Édouard Glissant. Referring to Glissant she write:

[P]oetics starts with a recognition of the immensity of loss, with the unspeakable... Like the storyteller who sings, "in utter solitude" to "the earth and those who suffer through it," ... His words are neither representation nor celebration, but an offering in a liturgy of lament.

... "What then is language? This cry that I elected?," asks Glissant... "Not only the cry, but absence beating in the cry." An "absence beating in the cry," .. And it is to this absence this silence and this involution that I bind in my throat my language, which thus begins with a lack (Rivera 2019: ). 
I return to Latour. To the torments of remaining with religious speech. Aware of the brokenness engulfing him and for reasons he cannot articulate he stays. I stay - because. Because something remains sacred amongst the shells of broken churches. Because it is better to be in this place than somewhere wounds are not acknowledged. Because even if there are no live coals upon the altar with which to touch our tongues, we would remain where broken walls remember the oldest, deepest love.

\section{Ruins Make Space Between Life and Death}

My second mode of reflection upon broken things continues on from the first and turns to broken places where life and death meet.

The temple walls will be brought down. What took generations to build up will be destroyed. The strongholds of faith will be utterly consumed. In this annihilation, in ending and dying, you will experience the strangest, sweetest movement of impossible life.

In A Field Guide to Getting Lost (2017), Rebecca Solnit writes 'What is a ruin after all?' Something vital to us. The place where culture surrenders to nature. Marked by vandalism, neglect, violence or simply age 'Ruins became the unconscious of a city, its memory [of] unknown darkness, lost lands' (2017: 89). Within these desolate places, in its ruins, the living city can contemplate and comprehend death.

Solnit is writing about the cultural significance of broken buildings. Ruins of broken concrete, and twisted metal. There are also fleshly sites of ruin. I have inhabited one of these. The place of infertility. In her passionate book on infertility and IVF Avalanche (2016) Julia Leigh offers an account of what it means to experience death in life. Of being possessed by creative desire that appears to meet no productive outcome. Of carrying loss in the body. Being pulverised by the blank weight of whiteness. And more. We hardly have words for this in our culture. Holding with love and a wild, fierce belief the presence of what is absent within you.

Leigh struggles to articulate her experience of the endless effort to conceive a baby. A child which is beloved to her but has only ever existed anywhere in the space of her longings. She writes, 'Our child was not unreal to me. It was not a real child but it was not unreal. Maybe a better way to say it is that the unknown, unconceived had been an inner presence. A desired and nurtured inner presence... in which I had radical faith' (2016: kindle location 355) In another effort to describe the same thing she offers this small narrative from her IVF journey

I was having trouble sleeping so in the middle of the night I walked down to the playground at the end of my street. All the ghost-children were at play. There were little boys crawling over webs of rope, little girls kicking up their heels on the swings. They sang and squabbled and thrilled at making footprints in the dirt. I told a girl I loved her outfit. 'It's not an outfit!' she said, 'It's a tiger suit!' (2016:kindle location 667).

Lost children in the park at night.

Rachel weeping for her children and she cannot be comforted because they are not. 
The Christian tradition has deep resources in its scriptures, but most particularly in its art, through which it contemplates the carrying of loss in the manner I am trying to image here. So we might think of the great pietas in which mothers bear death upon their curved laps. But we might also move from them to the figures that are often drawn at the base of the crucifixion those who would bear up the beloved - but cannot. We have the weeping Magdalene's reaching out to touch - but unable to touch. These all embody anguish; portray both human loss of the beloved and human loss of the divine beloved. Furthermore, they represent both separation and a refusal to be separated. A radical faith in what is absent but somehow also deeply present. Art is a powerful medium for reducing and retrieving the sacral power of these images beyond the ruins of faith. I recently encountered Francis Bacon's 'The Magdalene' ${ }^{1}$ in an Edinburgh gallary. Painted in 1945 it is the first one in which his famous open mouth appears - breaking into a rather conventional domestic setting and screaming its challenge of dereliction. This silent mouth I think discloses the torment of religious speech.

In his last great work, The Mystic Fable, the cultural theorist de Certeau writes: 'What should be there is missing.' The adored missing body. Writing 'sings its loss without being able to accept it' (). In my own life writing I have tried - in common-place narratives about growing up, doing stuff, thinking things, forming faith, seeking to conceive a child - I have sought to sing loss without accepting it and thus approach the ambiguous generative holy space of chaos, of life and death, ruins and radical faith. This is an extract from my last book Not Eden.

Everything has its mirror image. Eve spelled backwards is Eve.

I was Eve working in the garden tying in the raspberry canes and my hands and my lips were stained by mulberries too soft and sweet to gather. I wanted to bear good fruit but something happened in the night and there was blood on the grass in the morning and nothing would grow any more.

So now I am that other Eve. A small, dark person who lives by her wits in the savage garden. You have been told that the universe is a place of constant growth and regeneration. I am compelled ... to say that it is a barren, wasted place. For all the things that grow there are partners in things that never came into being. I am their mother and even if they are forgotten I shall remember them. I am their witness.

Once the Spirit said to me 'See how much is given'.

Now she whispers of what has been denied. So much has been denied. How many cold stars, how many frozen deep or burning hot stars for just this one green earth? And yet without them what motion, what fire or ice, except that which has been borrowed?

Perhaps one day she will lead me out of here, show me a place to clamber out beneath the barbed wire fence and inherit a green and golden portion. In dreams sometimes I do seem to taste her milk and honey. But when awake I am captured by the ....beauty of this wilderness. See how sweetly blow my poppies. How brightly they

\footnotetext{
${ }^{1}$ The painting has been renamed, 'Figure Study Two', but this was the original title.
} 
flower even in the churned up earth, growing amongst the twisted metal, from the patch of earth that is stained dark...

How beautifully grows the bindweed...It grows right to the top of the wire mesh fence. The only flowers they can see when they press their cheeks to the fence which is too high to be climbed and there is no escape from the beams of the arching lights. Mine are the only flowers that can grow in such a place. They are necessary.

And there in the corner blooms a fragment of the true cross. Blossoms coming straight out from the bare wood. I confess that it does not grow very strongly but it is a miracle that it grows at all... To you [maybe] it seems a false and pagan relic. I am not so sure. To me it is a mysterious thing and it certainly is alive - though in a way I cannot understand. It is stained dark. Perhaps this is holy blood. Or perhaps it bears the mark of all those who treasured it, kissed it, fought over it, haggled for it, traded it, stole it, passed it from hand to hand and touched it in the hope of a healing that never came.

I suppose that some of them were children.

The blossoms have a lovely scent (Walton, 2015: 136-7)

\section{Ruins Are Sites of Transformation}

My third reflection focusses ruins as sites of transformation.

Destroy this temple and I will raise it up. We did not understand then what this life from death might mean.

I have referred to Rose Macaulay and her literary wanderings amongst the debris of London submerged in a deep grief. She liked particularly the wrecked landscape around St Paul's and I do sometimes wonder if she met there another person who also sought out this terrain but with a rather different end in mind. The young artist Eduardo Paolozzi.

For Paolozzi too the war had been ruinous. His father, an Italian shopowner from Edinburgh had been interned and then deported to Canada on a ship that was torpedoed in transit. But Paolozzi's eyes were not on what had been lost so much as what ruins might bring forth.

Reflecting back upon her book Macaulay described the World my Wilderness as a prayer. An inarticulate, unconscious prayer amidst ruins. I have identified this as a moment within theopoesis - one that acknowledges and connects with destruction and keeps silent before speaking. I then went on to speak of a radical ambivalence ruins mediate allowing for the messy mingling of absence and presence; of life in death. Paolozzi takes us on from this place into a model of theopoetic construction or transformation. He would not have called it this. He had his own favourite phrase. What he called it was 'The metamorphosis of rubbish' the derelict and damaged reforming with piercing power. The artist, he stated (5) has the ability to 'achieve a metamorphosis of quite ordinary things into something wonderful and extraordinary' (Paolozzi 1968: 617 ). When he gleaned and salvaged amongst the bomb 
craters this was the work he was engaged in. A sacralization of oridnary things; broken, scarred and marked.

Paolozzi wandered around wrecked sites not searching for but being searched out by the debris they contained. The 'as found' objects which in truth claimed him rather than vice versa.

He listed some of his resources thus:

Dismembered lock

Toy frog

Rubber dragon

Toy camera

Assorted wheels and electrical parts

Clock parts

Broken comb

Bent fork...

Parts of a radio...

Shaped pieces of wood

Natural objects such as pieces of bark

Gramophone parts

Model automobiles (Paolozzi in Highmore, 2011: 89).

All of these 'as founds' were taken by him, pressed into clay, molded in wax, scored, rescored, rearranged and then formed into sculptures; metal forms of gods and creatures. Wounded bodies. which articulate, transform through practice, recreate the being of the found objects - in their absence. In what has become a legendary address to the institute of contemporary art in 1958 Paolozzi articulated from notes with headings that to me read as poetry where his artistic vision was leading.

This is what I have in mind...[he said]

A Fantastic

Autobiography

Project of a hundred faces

A fantastic project for a playground (perhaps for lost children)

Secret map

Secret word

Mud language

Written with object trouve and broken toys

The word written is to weep

Cry out a language

Sea light Sun Wheel..

Supply Maps to a

Creative...

Water signs and shadow language (Paolozzi, 2000). 
I think these words express the destination I have been trying to reach in this article. Indeed I don't really think the article is necessary if following Paolozzi we might just imagine theopoetics as this 'a mud language written in broken things that weeps and cries out, supplying maps for creativity. A new language of signs and shadows.' Interestingly, and as a bit of a gift to me, Paolozzi's address to the Institute was advertised under the title, 'Image Making - God Breaking'. This has that radical edge sound of the reforming brutalism with which he is also deeply associated. However, before he stood up to deliver his reflections on the metamorphosis of rubbish the Chair corrected a typographical error. The title should have been 'Image breaking - God making' he announced (Highmore, 2011, 87). God making. Paolozzi was lecturing on theopoetics. How wonderful. I do like these 'as found' happenstances in the universe.

I have another fragment to place here. I have spoken about infertility but after years of waiting I did at last become a mother. My child was conceived through IVF which is a very arduous process involving a whole series of interventions before the implantation procedure takes place. On the very day of this event I was having a very early morning cup of tea in bed and listening to the radio. Coincidentally it was the beginning of Advent and as the daily devotional broadcast floated across the room I heard these words spoken to me. 'Behold you will conceive and bear a son'. 'My God!' I thought - you can imagine. However, I did not have a son. I had a daughter. But there is no text in the Bible that says 'Behold you will become pregnant with a girl-child.' So what was available to work with in terms of the sacred tradition is pretty limited. This was probably the nearest the divine could get in the circumstances. I have heard similar arguments but forward as to why Jesus was a man - we have to work with what's available. But If you want to speak to a feminist why use sacred tradition at all. Why not choose some other medium. Indeed why not?

But then what is a sacred tradition, what is a theological building, or a theopoetic body come to that? Is it not the case that my own every day annunciation both affirms and skews the tradition. May not my Eve join her fairer sister in the garden? Or linger in the ruins of the holy places women previously could not inhabit? The tradition is not fixed or given. It is already heterogeneous and composed of the 'as founds' which claim us. ${ }^{2}$ As Keller asserts, theology 'was always tangling with the traditions that preceded or confronted it, with elemental goddesses and golden calves, critical philosophies, secular sciences imperial soveriegnites, social revolutions. All, really all, still participating in the body of theology. This carnal multiplicity can no longer be kept out of sight (2017:6)'.

So this is my vision of theopoetics; a project in ruins. Sacred speech that touches earth and employs mud language. This is my understanding of my own vocation; to be a poet of the broken form enfolded in death and resurrection, but not as a journey between fixed points, but as a mode of messy being between worlds of wonder and horror. And nor is resurrection, restoration, rebuilding or renewal. It is a new incarnation...'We did not understand he was speaking of the body.'

\section{Bibliography}


Begbie, Jeremy. 2002. "Introduction". In Sounding the Depths: Theology Through the Arts, edited by Jeremy Begbie, 1-13. London: SCM Press.

Bennett, Jane. 2015 "Encounters with an Art Thing". Evental Aesthetics. 3.3. 91-105.

Bennett, Jane. 2001. The Enchantment of Modern Life: Attachments, Crossings and Ethics. Princeton, NJ: Princeton University Press.

Blanchot, Maurice. 1995. The Writing of the Disaster, translated by Ann Smock. Lincoln, Neb : University of Nebraska Press.

Caputo, John. 2006. The Weakness of God: A Theology of the Event. Bloomington, IN: Indiana University Press.

Caputo, The Theopoetic Reduction: Suspending the Supernatural Signified, Literature and Theology. tbc

Celan, Paul 2011. The Meridian: Final Version-Drafts-Materials, translated by Pierre Joris; edited by Bernhard Böschenstein and Heino Schmull. Stanford, CA: Stanford University Press. Conolly, William. 2012. The Fragility of Things. Durham, NC: Duke University Press.

Certeau, Michel de. 1995. The Mystic Fable, Volume One, The Sixteenth and Seventeenth Centuries, translated by Michael Smith. Chicago: University of Chicago Press.

Collins, Lorna. 2016. Making Sense: Art Practice and Transformative Therapeutics. London: Bloomsbury.

Connolly, William. 2013. Self-Organizing Processes, Neoliberal Fantasies, and Democratic Activism. Durham: Duke University Press.

Derrida, Jacques. 2001. Writing and Difference, $2^{\text {nd }}$ ed., translated by Alan Bass. (New York; London: Routledge.

Glissant, Édouard. 1997. Poetics of Relation, translated by Betsy Wing. Ann Arbor : University of Michigan Press.

Highmore, Ben. 2011. "Image-breaking, God-making": Paolozzi's Brutalism." October 136. 87104

Hopkins, Gerard Manley. 1976. 'As kingfishers catch fire, dragonflies draw flame', in W.H. Gardener (ed.), Gerard Manley Hopkins Poems and Prose, Harmondsworth: Penguin p.51 
Kearney, Richard. 2018 "God Making: Theopoetics and Anatheism". In The Art of Anatheism, edited by Richard Kearney and Matthew Clemente, 3-28. London: Rowman and Littlefield International.

Kearney, Richard. 2015a. "God After God". In Reimagining the Sacred: Richard Kearney Debates God, edited by Richard Kearney and Jens Zimmermann, 6-18.

Kearney, Richard. 2015b. 'Transcendent Humanism in a Secular Age'. In Reimagining the Sacred: Richard Kearney Debates God, edited by Richard Kearney and Jens Zimmermann, 7692

Kearney, Richard. 2011. Anatheism: Returning to God after God. New York: Columbia University Press.

Keller, Catherine. 2018. "Theopoetics: A Becoming History". In The Art of Anatheism ,edited by Richard Kearney and Matthew Clemente, 29-42. London: Rowman and Littlefield International.

Keller, Catherine. 2017. Intercarnations: Exercises in Theological Possibilty. New York: Fordham University Press.

Keller, Catherine. 2015. Cloud of the Impossible: Negative Theology and Planetary Entanglement. New York: Columbia University Press.

Keller, Catherine. 2013. "Theopoiesis and the Pluriverse: Notes on a Process". In, Theopoetic Folds: Philosophizing Multifariousness, edited by Roland Faber and Jeremy Fackenthal, 17984. New York: Fordham University Press.

Keller, Catherine. 2012. "The Energy We Are: A Meditation in Seven Pulsations". In Cosmology, Ecology and the Energy of God, edited by Donna Bowman and Clayton Crockett, 11-25. New York: Fordham University Press.

Keller, Catherine. 2008. On the Mystery: Discerning God in Process. Minneapolis: Fortress.

Latour, Bruno. 2013. Rejoicing: Or the Torments of Religious Speech. Translated by Julie Rose. Cambridge: Polity Press.

Lefebvre, Henri. 2005. Critique of Everyday Life, vol. 3: From Modernity to Modernism: (Towards A Metaphilosophy Of Daily Life), translated by Gregory Elliott, London: Verso Leigh, Julia. 2016. Avalanche: A Love Story. London: Faber and Faber Miller, David Leroy. 2010. "Theopoetry or Theopoetics?," Cross Currents 60, no. 1 (2010): 623

Lévi-Strauss, Claude. 2004. The Savage Mind. Oxford: Oxford University Press. 
Macaulay, Rose. 1983. The World My Wilderness. London: Virago.

Milbank, John. 2013. Beyond Secular Order: The Representation of Being and the Representation of the People. Oxford: Wiley Blackwell

Nussbaum, Martha. 1992. Love's Knowledge: Essays on Philosophy and Literature. Oxford: Oxford University Press.

Rambo, Shelly. 2017. Resurrecting Wounds: Living in the Aftermath of Trauma. Wacko TX: Baylor University Press.

Rambo, Shelly 2019. "The Posture of Words". Literature and Theology. tbc

Rivera, Mayra. 2015. Poetics of the Flesh: Durham and London: Duke University Press

Rivera, Mayra. 2019. "Poetics Ashore". tbc

Smith, James. 2014. How Not to Be Secular: Reading Charles Taylor. Grand Rapids: Eerdmans.

Solnit, Rebecca. 2017. A Field Guide to Getting Lost. Edinburgh: Canongate.

Paolozzi, Eduard. 2000. 'Notes from a Lecture at the Institute of

Contemporary Arts' in Eduardo Paolozzi: Writings and Interviews, ed. Robin Spencer, Oxford: Oxford University Press, pp. 80-6.

Paolozzi, Eduard. 1968. 'Interview' in Herschel B. Chipp ed. Theories of Modern Art: Source Book by Artists and Critics. Berkley: University of California Press. 617.

Taylor, Charles. 2007. A Secular Age. Cambridge, Mass: The Belknap Press.

Walton, Heather. 2011. "When Love Is Not True". In Literature and Theology: New Interdisciplinary Spaces edited by Heather Walton, 37-54. Abingdon: Routledge

Walton, Heather.2015. Not Eden: Spiritual Life Writing for this World. London: SCM Press.

Walton, Heather (2019) A Theopoetics of Practice: e-forming in Practical Theology. International Journal of Practical Theology, 23(1), pp. 3-23. 